\title{
Antifreeze proteins promote the germination of low temperature-treated petunia seeds via regulation of antioxidant- and proline-related genes
}

\author{
Phyo Phyo Win Pe $\cdot$ Swum Yi Kyua $\cdot$ Aung Htay Naing $\cdot$ Kyeung Il Park $\cdot$ Mi-Young Chung $\cdot$ Chang Kil Kim
}

Received: 14 September 2020 / Revised: 18 September 2020 / Accepted: 18 September 2020

(c) Korean Society for Plant Biotechnology

\begin{abstract}
The involvement of antifreeze proteins (AFPs; type I and III) in the germination of low temperature-treated petunia seeds (cv. 'Mirage Rose') was investigated. The addition of AFPs (300 or $500 \mu \mathrm{g} / \mathrm{l})$ in low-temperature treatment significantly promoted the germination of seeds compared with that in which AFPs were not added. Among all treatments, treatment with AFP I added at $300 \mu \mathrm{g} / 1$ showed the highest germination percentage and improved plant growth. The expression levels of antioxidant-related genes such as superoxide dismutase, peroxidase, and proline synthesis were associated with the germination of low temperature-treated seeds. Overall, this study demonstrated that AFP I may potentially function as a cold-protective agent for the germination of low temperature-treated seeds.
\end{abstract}

Keywords Germination, Gene expression, Low temperature, Plant growth, Petunia hybrida

\section{Introduction}

The influence of temperature in the mechanism of seed germination has been reported in several crops, including Pittosporum, Salicornia rubra, and tomato (Bewley 1982; Khan et al. 2000; Mobayen 1980; Moore et al. 1994; Kyu et al. 2019). Pittosporum seeds exposed to low temperatures $\left(4^{\circ} \mathrm{C}\right)$ were shown to exhibit rapid germination (Moore et

P. P. W. Pe $\cdot$ K. I. Park

Department of Horticulture and Life science, Yeungnam University, Gyeongsan, South Korea

S. Y. Kyua $\cdot$ A. H. Naing $\cdot$ C. K. Kim (四)

Department of Horticultural Science, Kyungpook National University, Daegu, South Korea

e-mail: ckkim@knu.ac.kr

M.-Y. Chung

Department of Agricultural Education, Sunchon National University, Suncheon, South Korea al. 1994). Similarly, purple cauliflower seeds also exhibited improved germination when exposed to a low temperature $\left(10^{\circ} \mathrm{C}\right.$; Wartidiningsih et al. 1994). However, inhibition of seed germination at low temperatures $\left(5^{\circ} \mathrm{C} \sim 15^{\circ} \mathrm{C}\right)$ was observed in S. rubra (Khan et al. 2000). In case of tomato seeds, a specific temperature $\left(11^{\circ} \mathrm{C} \sim 25^{\circ} \mathrm{C}\right)$ is required for seed germination, and temperatures below $10^{\circ} \mathrm{C}$ delay germination (Mobayen, 1980). Similarly, Foolad and Lin (2000) and Kyu et al. (2019) observed inhibition of tomato seed germination at low temperatures. Generally, low temperatures induce reactive oxygen species (ROS) in various cellular compartments of seeds (Scandalios 2005). It also negatively affects seed physiology (Bailly 2004), leading to seed deterioration (Bailly et al. 2008).

The effects of low temperature on seed germination have not been investigated in petunia, which is a popular ornamental bedding plant in landscape industries as well as a model crop in biotechnology research. In fact, both tomatoes and petunias belong to the family Solanaceae. It was therefore interesting to investigate the effects of low temperature on petunia seed germination. The protective role of antifreeze proteins (AFPs) against low temperatures was recently reported in various plant species (Jeon et al. 2015; Seo et al. 2018; Pe et al. 2019). Jeon et al. (2015) and Seo et al. (2018) reported that the use of AFP type III positively affected the cryopreservation efficiency of chrysanthemums and potatoes. The transcriptional variation of cold-responsive genes in plants through AFPs (type I and type III) was also observed (Pe et al. 2019). Kyu et al. (2019) recently reported that AFP-treated tomato seeds promoted tomato seed germination by regulating the expression levels of major antioxidant-related genes, including superoxide dismutase $(S O D)$ and catalase $(C A T)$. This minimizes abiotic stress-induced oxidative stress by scavenging ROS in cells (Mittler et al. 2004; Murshed et al. 2014; Wu et al. 2004; $\mathrm{Xu}$ et al. 2010). Therefore, investigating the 
function of AFPs in the germination mechanism of petunia seeds under low temperatures would be interesting.

In this study, we investigated the function of AFPs in the germination of petunia seeds subjected to a low temperature $\left(4^{\circ} \mathrm{C}\right)$ for 5 days $(\mathrm{d})$, followed by maintenance at a normal temperature $\left(20^{\circ} \mathrm{C}\right)$ for $15 \mathrm{~d}$. Germination percentages and transcript levels of the genes associated with germination were determined.

\section{Materials and Methods}

Materials

Petunia hybrida cv. 'Mirage Rose' seeds were used as source material for this experiment.

AFP treatment

The seeds were pretreated with various concentrations of two AFPs (type I and type III), which were derived from fish (A/F Protein Inc., Waltham, MA, USA), and sown for germination, as described by Kyu et al. (2019). Briefly, the seeds were immersed in water containing various concentration of AFPs $(0,300$, and $500 \mu \mathrm{g} / \mathrm{l})$ for $24 \mathrm{~h}$. Seeds immersed in water only (without AFPs, $0 \mu \mathrm{g} / \mathrm{l}$ ) were used as the control.

\section{Effect of AFPs on seed germination}

The AFP-treated seeds were sown in a seedling tray filled with a soil-less mixture (BM7; Berger Co., Quebec, Canada). The tray was placed in a growth chamber set at a fixed temperature $\left(4^{\circ} \mathrm{C}\right)$, with a $16 \mathrm{~h}$ photoperiod and $70 \%$ relative humidity, for $5 \mathrm{~d}$. The seeds were allowed to grow at a normal temperature $\left(20^{\circ} \mathrm{C}\right)$ for $15 \mathrm{~d}$. Each treatment consisted of 30 seeds with three replications. For all treatments, the germination percentage was recorded at 10,12 , and $14 \mathrm{~d}$ after sowing (DAS). The number of leaves per plant and fresh weight were recorded at 14 DAS.

Expressional analysis of antioxidant-related genes

RNA was extracted from the leaves of 14-d-old petunia seedlings using an RNAqueous kit (Ambion Inc., Austin, TX, USA). Complementary DNA (cDNA) was synthesized from $1 \mu \mathrm{g}$ of total RNA using ReverTra Ace- $\alpha$ (Toyobo Co., Ltd., Osaka, Japan). The expression levels of antioxidant-related genes (SOD, CAT, and peroxidase $[P O D]$ ) and proline synthesis gene (Osmotin) were analyzed using the StepOnePlus Real-Time PCR System (Thermo Fisher Scientific, Inc., Waltham, MA, USA). The tubulin gene was used as a reference gene for the normalization of gene expression levels. The primers and PCR conditions used for gene amplification are listed in Supplementary Table 1. Three different biological samples were used for the expression analysis.

Data analysis

Data were analyzed using SPSS version 11.09 (IBM Corporation, Armonk, NY, USA). The data represent the mean of three replications. Duncan's multiple range test $(\mathrm{P}<.05)$ was used for statistical analyses.

\section{Results}

Petunia seeds that were sown under normal growth temperature $\left(20^{\circ} \mathrm{C}\right)$ germinated at 5 DAS (data not shown). However, this was not observed at low temperature $\left(4^{\circ} \mathrm{C}\right)$ for all treatments regardless of AFP treatment. When the seeds were transferred to normal growth conditions $\left(20^{\circ} \mathrm{C}\right)$, germination was observed at 10 DAS and germination rates peaked at 12 DAS. The germination percentage of AFP-treated seeds was significantly higher than that of non-AFP-treated seeds (control), except for AFP III (500 $\mu \mathrm{g} / \mathrm{l})$ (Fig. 1). When the germination percentages were further assessed at 14 DAS, significant improvements were not observed in seeds treated with AFP I but were observed in seeds treated with AFP III $(300 \mu \mathrm{g} / \mathrm{l})$. In addition, the germination percentage between the two concentrations of AFP I was not significantly different at 10, 12, and 14 DAS. A significant difference was observed for AFP III (300 and $500 \mu \mathrm{g} / \mathrm{l})$, especially at 14 DAS. However, in terms of growth performance of the germinated seedlings, those treated with AFP I $(300 \mu \mathrm{g} / \mathrm{l})$ showed the best growth, followed by those treated with AFP I (500 $\mu \mathrm{g} / \mathrm{l})$. The growth performance of seeds treated with AFP III and control was not different (Fig. 2). This was confirmed by measuring their fresh weights (Fig. 3). Significantly higher fresh weights were observed in the following order: [AFP I $(300 \mu \mathrm{g} / \mathrm{l})>$ AFP I $(500 \mu \mathrm{g} / \mathrm{l})>$ AFP III $(300 \mu \mathrm{g} / \mathrm{l})$, AFP III $(500 \mu \mathrm{g} / \mathrm{l})$, and control)]. Therefore, AFP I (300 $\mu \mathrm{g} / \mathrm{l})$ is better suited for the low temperature-treated seed germination of 'Mirage Rose'. 
(a)

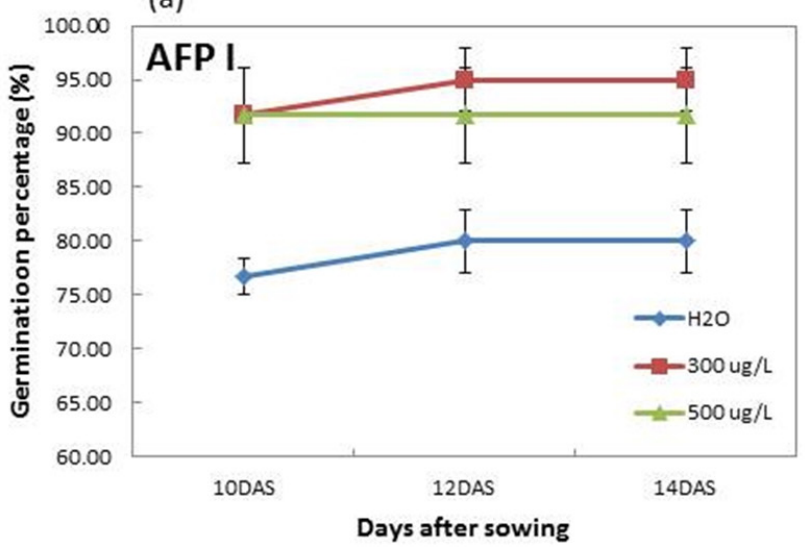

(b)

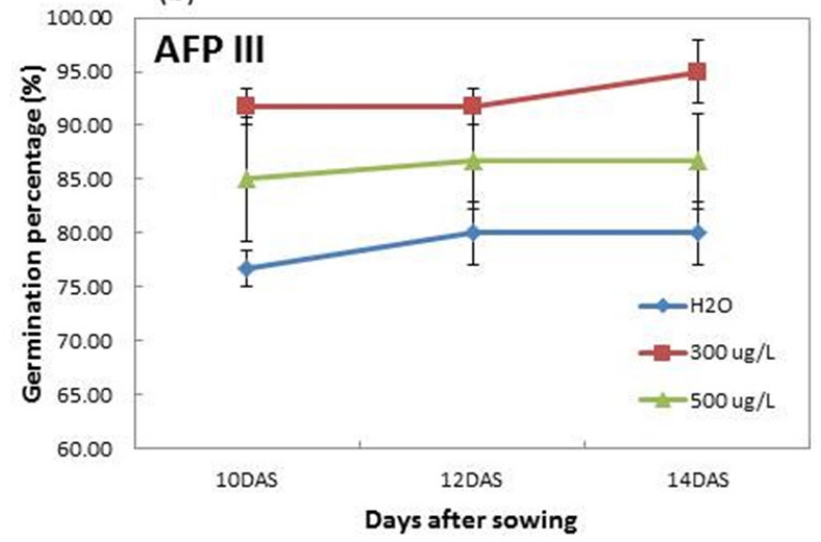

Fig. 1 Germination percentages of petunia seeds treated with or without antifreeze protein type I (a) and type III (b) under specific growing conditions (at $4^{\circ} \mathrm{C}$ for $5 \mathrm{~d}$, followed by $20^{\circ} \mathrm{C}$ for $9 \mathrm{~d}$ ). In control treatment, the seeds were soaked in water only. Data represent the means of the replications, and bars indicate standard errors of the three replications

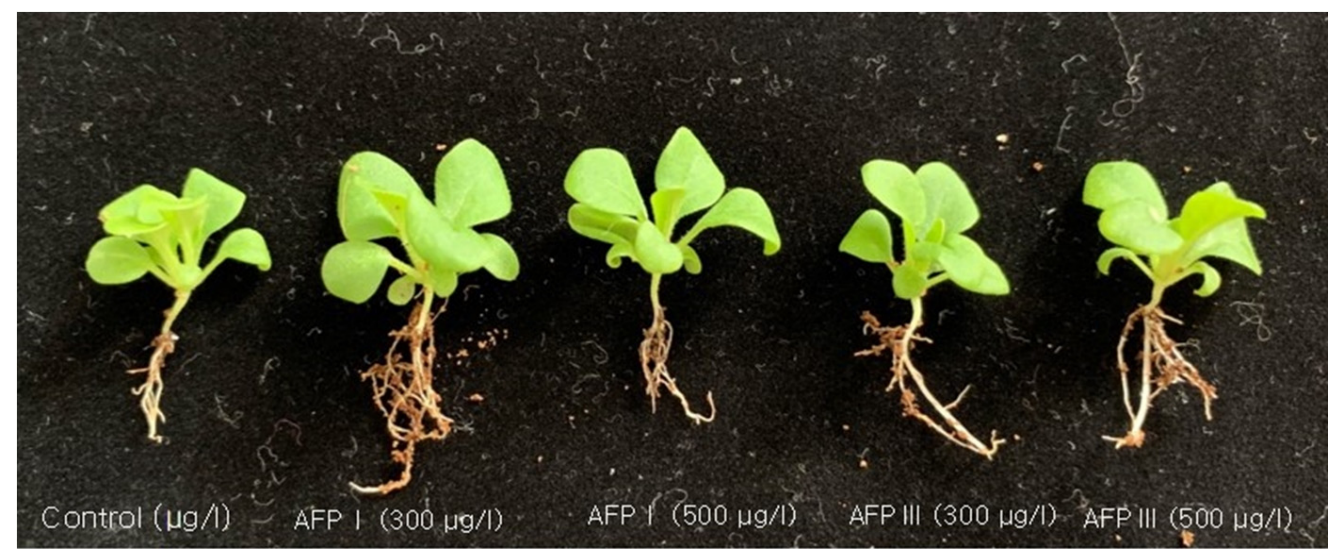

Fig. 2 Illustration of the growth performance of seedlings germinated from petunia seeds treated with AFP I and III (300 and $500 \mu \mathrm{g} / \mathrm{l})$ and control $(0 \mu \mathrm{g} / \mathrm{l})$

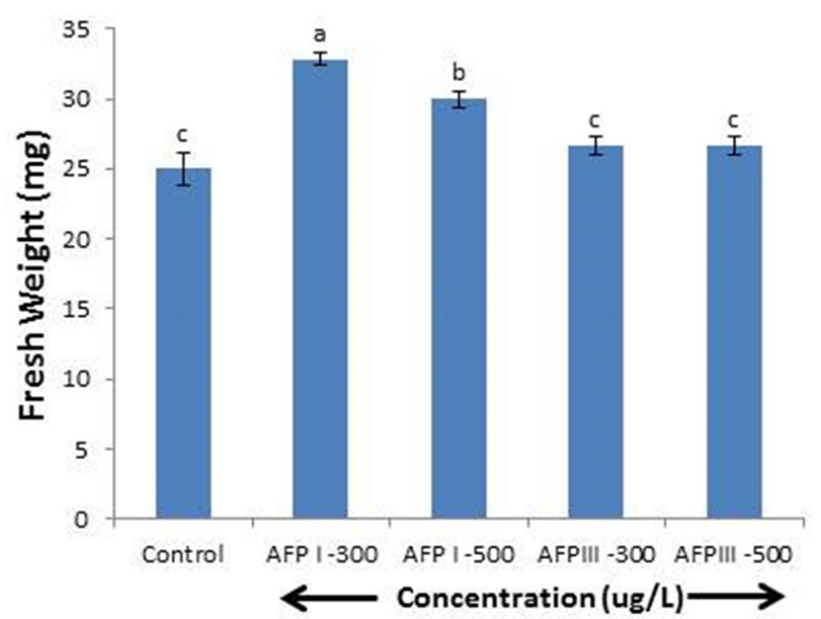

Fig. 3 Fresh weights of seedlings germinated from petunia seeds treated with AFP I and III (300 and $500 \mu \mathrm{g} / \mathrm{l})$ and control $(0 \mu \mathrm{g} / \mathrm{l})$. Data represent the means of the replications, and bars indicate standard errors of three replications. Means with the same letters are not significantly different by DMRT $(p<0.05)$
Transcriptional analysis of genes involved in seed germination

As shown in Figure 1, the germination percentages of the AFP-treated seeds varied depending on the type of AFPs and their concentrations. To determine the molecular mechanism underlying the variation in germination percentages among the AFP treatments, we investigated how AFPs affected the expression of the genes (SOD, POD, CAT, and Osmotin) associated with germination using RT-qPCR. As shown in Figure 4, the gene expression levels of the seedlings varied depending on the concentrations and types of AFPs. Specifically, Osmotin expression was upregulated in the seedlings germinated from control seeds $(0 \mu \mathrm{g} / \mathrm{l})$, with a transcript level significantly higher than that in seedlings germinated from seeds treated with AFPs. $S O D$ expression patterns resembled those of Osmotin, with higher expression levels in control plants than in those treated with AFPs. However, CAT expression levels in both control 

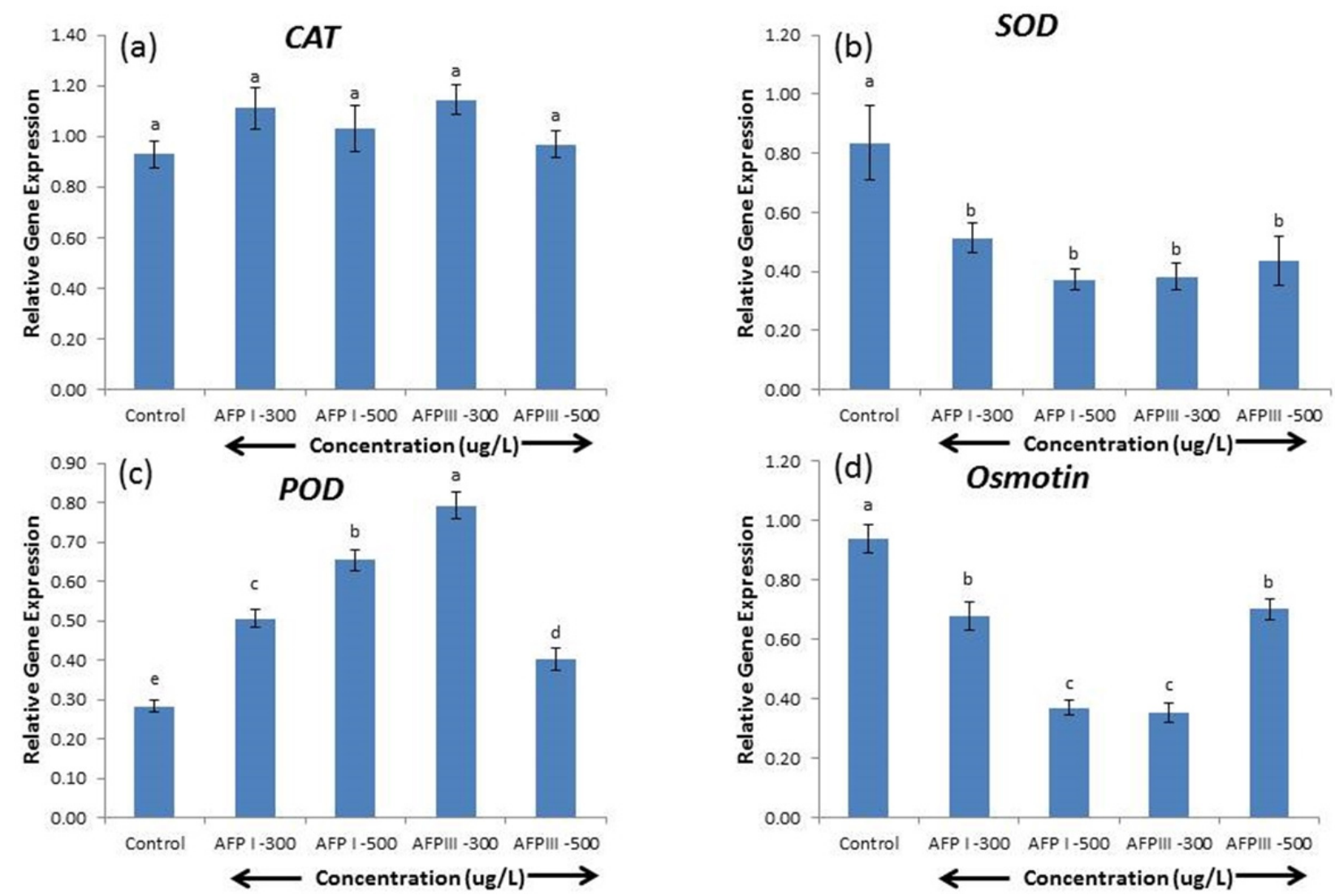

Fig. 4 Expression levels of antioxidant-related genes $C A T$ (a), SOD (b), and POD (c) and proline synthesis gene Osmotin (d) expressed in seedlings germinated from seeds treated with or without antifreeze proteins (AFPs) type I and III under low temperature conditions (at $4^{\circ} \mathrm{C}$ for $5 \mathrm{~d}$, followed by $20^{\circ} \mathrm{C}$ for $9 \mathrm{~d}$ ). Control indicates seeds soaked in water only. Data represent the means of the biological replicates, and bars indicate standard errors of three replicates. Means with the same letters are not significantly different by DMRT $(\mathrm{p}<0.05)$

seedlings and AFP-treated seedlings were not significantly different. In addition, $P O D$ expression was upregulated in seedlings treated with AFPs, with transcript levels significantly higher than those of control seedlings (Fig. 4).

\section{Discussion}

Temperature plays an important role in seed germination, but the optimum temperature varies depending on the plant species. For example, lower temperatures $\left(4^{\circ} \mathrm{C}\right.$ and $\left.10^{\circ} \mathrm{C}\right)$ are optimal for the germination of Pittosporum and purple cauliflower seeds, respectively (Moore et al. 1994; Wartidiningsih et al. 1994). Conversely, temperatures of $5^{\circ} \mathrm{C} \sim$ $15^{\circ} \mathrm{C}$ were found to significantly inhibit germination of $S$. rubra seeds (Khan et al. 2000). Similarly, inhibition of seed germination at low temperatures was observed in tomatoes (Foolad and Lin 2000), for which higher temperatures $\left(11^{\circ} \mathrm{C} \sim 25^{\circ} \mathrm{C}\right)$ are required for seed germination (Mobayen, 1980). Kyu et al (2019) recently reported that AFP I could be used as a cold-protective agent for tomato seed germination at low temperatures. In addition, a similar role of AFPs in cryopreservation of chrysanthemums and potatoes was reported (Jeon et al. 2015; Seo et al. 2018). Despite investigations on the role of AFPs in other Solanaceae crops, such as tomatoes and potatoes, its role has not been tested in petunias. Therefore, the role of AFPs in the germination of petunia seeds exposed to a low temperature $\left(4^{\circ} \mathrm{C}\right.$ ) for $5 \mathrm{~d}$, followed by $20^{\circ} \mathrm{C}$ for $15 \mathrm{~d}$, was investigated.

Despite observations of petunia seed germination at 5 DAS under normal growth conditions, seeds treated with or without AFPs did not germinate even when they were transferred from a low-temperature condition $\left(4^{\circ} \mathrm{C}\right)$ to normal growing condition for a few days. It is possible that mitotic cell division was inhibited by the low temperature (Simon et al. 1976) because the inactivation of mitotic cell division inhibits seed germination and early seedling growth (Masubelele et al. 2005). As observed for petunias, inhibition of seed germination by low temperatures was reported in other Solanaceae crops, including eggplant, pepper, and tomato 
(Wilcox and Pfeiffer, 1990).

Seed germination started on day 5 (10 DAS) after being transferred to $20^{\circ} \mathrm{C}$ for all treatments. During the germination period, the germination percentages for the AFP treatments (300 and $500 \mu \mathrm{g} / \mathrm{l}$ ) were significantly higher than those for the control. Reduced germination percentages of the control seeds could be attributed to cell injury caused by lowtemperature stress. The higher germination percentages of AFPs -treated seeds could be a result of the cold-protective role of AFPs because AFPs could prevent cell damage due to low temperatures. In this study, the germination initiation date was the same for both AFP I and AFP III treatments, and both played similar roles in seed germination. This was not consistent with the result of Kyu et al. (2019), who reported a more positive role of AFP I in tomato seed germination than AFP III. Kyu et al. (2019) further observed that the germination percentage of AFP III-treated seeds was lower than that of control seeds $(0 \mu \mathrm{g} / \mathrm{l})$ at 20 DAS. This discrepancy could be due to differences in the nature of tomato and petunia seeds. However, the plant growth performance observed with AFP I treatment was distinctly better than that observed with AFP III treatment, in which the growth performance was similar to that of the control. Although AFP III treatment could enhance seed germination, it may exert toxic effects on the seeds, resulting in slow seedling growth. Some adverse effects of AFP III have also been reported in previous studies (Naing and Kim 2019). Furthermore, AFP I has been shown to have more effective utilization than AFP III in cryopreservation (Naing and Kim 2019).

Abiotic stress-induced ROS production in plant cells has been reported (Scandalios 2005). In addition, the role of enzymatic antioxidants such as SOD, POD, and CAT and proline in the reduction of oxidative stress by scavenging ROS in plant cells has also been reported (Mittler et al. 2004; Murshed et al. 2014; Naing et al. 2017; Wu et al. 2004; Xu et al. 2010). In the present study, the expression levels of $S O D$ and Osmotin were linked to seed germination. Downregulation of the gene expression levels with AFP treatments compared with that in the control treatment could be due to the fact that these genes were strongly induced by the control treatment to protect the cell membrane from oxidative damage under cold stress, and moderate transcript expression levels induced by AFP treatments might be due to the cold-protective role of AFPs. However, the expression level of $C A T$ did not differ significantly among the AFP treatments and the control, suggesting no involvement of CAT in seed germination of petunias. In a study on tomatoes, $S O D$ and $C A T$ were found to be involved in seed germination (Kyu et al. 2019). In the present study, $P O D$ expression levels were higher in the AFP treatments than in the control. This could be attributed to the inhibitory effect of low temperature on peroxidase activity in the seeds because inhibition of POD activity in the endosperm of wheat seeds at low temperatures has been reported (Bakalova et al. 2004). Thus, higher POD expression in the AFP treatments could be due to the cold-protective effects of AFPs during the germination of the cold-treated seeds. Collectively, these results highlight how cold stress may affect seed germination of petunias and indicate the potential of AFPs as cold-protective agents in the germination of cold-treated petunia seeds.

\section{Conclusion}

This study demonstrated the inhibition of petunia seed germination under low-temperature conditions and possible utilization of AFPs as cold-protective agents during seed germination. AFP I was found to have a greater positive effect on seed germination and seedling growth than AFP III. The effects of AFPs on seed germination were associated with the expression levels of antioxidant-related genes $(S O D$ and $P O D)$ and proline synthesis gene (Osmotin). This study suggests a greater viability of AFP I as a coldprotective agent in the germination of cold-treated seeds. It also provides a better understanding of how AFPs promote seed germination via the reduction of cold injury during seed germination.

\section{Acknowledgement}

This work was supported by a grant from the New Breeding Technology Program (Project no. PJ01485801), Rural Development Administration, Republic of Korea.

\section{References}

Bailly C, El-Maarouf-Bouteau H, Corbineau F (2008) From intracellular signaling networks to cell death: the dual role of reactive oxygen species in seed physiology. C R Biol 331: 806-814. doi:10.1016/j.crvi.2008.07.022

Bailly C (2004) Active oxygen species and antioxidants in seed biology. Seed Sci Res 14:93-107. doi:10.1079/SSR2004159. 2004

Bakalova S, Nikolova A, Nedeva D (2004) Isoenzyme profiles of peroxidase, catalase and superoxide dismutase as affected by 
dehydration stress and ABA during germination of wheat seeds. J Plant Physiol 30:64-77

Bewley JD, Black M (1982) Physiology and biochemistry of seeds in relation to germination. Berlin, Germany: Springer-Verlag 2:297, 304

Foolad MR, Lin GY (2000) Relationship between cold tolerance during seed germination and vegetative growth in tomato: germplasm evaluation. J Am Soc Hortic Scil 25:679-683. doi:10.21273/ JASHS.125.6.679

Jeon SM, Naing AH, Park KI, Kim CK (2015) The effect of antifreeze protein on the cryopreservation of chrysanthemums. Plant Cell Tiss Org 123:665-671. doi:10.1007/s11240-015-0852-x

Khan MA, Gul B, Weber DJ (2000) Germination responses of Salicornia rubra to temperature and salinity. J Arid Environ. 45:207-214. doi:10.1006/jare.2000.0640

Kyu SY, Naing AH, Pe PPW, Park KI, Kim CK (2019) Tomato seeds pretreated with Antifreeze protein type I (AFP I) promotes the germination under cold stress by regulating the genes involved in germination process. Plant Signaling \& Behavior 14(12), e 1682796 (6 pages) doi.org/10.1080/15592324. 2019.1682796

Masubelele NH, Dewitte W, Menges M, Maughan S, Collins C, Huntley R, Nieuwland J, Scofield S, Murray JAH (2005) D-type cyclins activate division in the root apex to promote seed germination in Arabidopsis. Proc Nat Acad Sci, USA 102:15694-15699. doi:10.1073/pnas.0507581102

Mittler R, Vanderauwera S, Gollery M, Van Breusegem F (2004) Reactive oxygen gene network of plants. Trends Plant Sci 9:490-498. doi:10.1016/j.tplants.2004.08.009

Mobayen RG (1980) Germination and emergence of citrus and tomato seeds in relation to temperature. J Hortic Sci 55:291297. doi:10.1080/00221589.1980.11514937

Moore S, Bannister P, Jameson P (1994) The effect of low temperatures on seed germination of some New Zealand species of Pittosporum. New Zeal J Bot 32:483-485. doi:10.1080/ 0028825X.1994. 10412934

Murshed R, Lopez-Lauri F, Sallanon H (2014) Effect of salt stress on tomato fruit antioxidant systems depends on fruit devel- opment stage. Physiol Mol Biol Plants 20:15-29. doi:10.1007/ s12298-013-0209-z

Naing AH, Win NM, Han J-S, Lim KB, Kim CK (2017) Role of Nano-silver and the Bacterial Strain Enterobacter cloacae in Increasing Vase Life of Cut Carnation 'Omea'. Front Plant Sci 8: 1590.doi: 10.3389/fpls.2017.01590

Naing AH, Kim CK (2019) A brief review of applications of antifreeze proteins in cryopreservation and metabolic genetic engineering. Biotech 9:329

Pe PPW, Naing AH, Chung MY, Park KI, Kim CK (2019) The role of antifreeze proteins in the regulation of genes involved in the response of Hosta capitata to cold. Biotech 9:335

Scandalios, JG (2005) Oxidative stress: molecular perception and transduction of signals triggering antioxidant gene defenses. Braz J Med Biol Res 38:995-1014. doi:10.1590/S0100-879X 2005000700003

Seo JH, Naing AH, Jeon SM, Kim CK (2018) Anti-freezing-protein type III strongly influences the expression of relevant genes in cryopreserved potato shoot tips. Plant Mol Biol 97:347-355. doi:10.1007/s11103-018-0743-8

Simon EW, Minchin A, McMenamin MM, Smith JM (1976) The low temperature limit for seed germination. New Phytol 77:301-311. doi:10.1111/nph.1976.77.issue-2

Wartidiningsih N, Geneve RL, Kester ST (1994) Osmotic priming or chilling stratification improves seed germination of purple coneflower. HortScience 29:1445-1448. doi:10.21273/ HORTSCI. 29.12.1445

Wilcox GE, Pfeiffer CL (1990) Temperature effect on seed germination, seedling root development and growth of several vegetables. J Plant Nutr 13:1393-1403. doi:10.1080/01904 169009364161

Wu CA, Yang GD, Meng QW, Zheng CC (2004) The cotton GhNHX1 gene encoding a novel putative tonoplast $\mathrm{Na}+\mathrm{H}+$ antiporter plays an important role in salt stress. Plant Cell Physiol 45:600-607. doi:10.1093/pcp/pch071

Xu SC, Li YP, Hu J, Guan YJ (2010) Responses of antioxidant enzymes to chilling stress in tobacco seedlings. Agri Sci China 9:1594-1601. doi:10.1016/S1671-2927(09)60256-X 